\title{
Study of Genetic Variability in Different Soybean Genotypes Based on Yield and Yield Contributing Traits
}

\author{
M. G. Pawar", S. B. Chaudhary, V. S. Pawar and S. B. Chavan \\ Department of Agricultural Botany, M.P.K.V., Rahuri (Maharashtra), India \\ *Corresponding author
}

\begin{abstract}
A B S T R A C T
The present investigation was undertaken to study the extent of genetic variability, heritability (b.s.), genetic advance, genotypic and phenotypic coefficient of variation, correlation, path analysis, genetic divergence among thirty genotypes of soybean. These genotypes were evaluated during Kharif, 2018 in a randomized block design with three replications. Observations were recorded on days to 50 percent flowering, days to maturity, plant height $(\mathrm{cm})$, number of primary branches per plant, number of pods per plant, number of seeds per pod, 100 seed weight $(\mathrm{g})$, seed yield per plant (g), SPAD value, protein content $(\%)$, oil content (\%). The treatment differences were statistically significant for all the characters. The phenotypic coefficient of variation (PCV) was found to be marginally higher than the genotypic coefficient of variation (GCV) for all the characters, indicating the dominance of the genotypic coefficient of variation for expression of these traits. Number of seed yield per plant exhibited the high GCV as well as PCV followed Number of pods per plant, plant height, number of seeds per pod, and 100 seed weight. The oil content exhibited the least GCV and PCV. Maximum heritability observed for the number of pods per plant (94.96), followed by plant height (93.11) and days to 50 percent flowering (91.38). The highest genetic advance estimates for the number of pods per plant, followed by plant height and days to maturity. The highest genetic advance as a percentage of mean was observed seed yield per plant followed by the number of pods per plant and plant height.
\end{abstract}

\section{Keywords}

Soybean, Genetic variation, Genetic advance,

Heritability, Soybean, Selection intensity, Traits

\section{Article Info}

Accepted:

07 August 2020

Available Online:

10 September 2020

\section{Introduction}

Soybean (Glycine max L. Merril) is considered a miracle crop due to of its extraordinary qualities. It is grown in East and South East Asia mainly for food, feed, and medicinal purposes. This plant contains about $38-42 \%$ of high-quality protein, $6 \%$ ash, $29 \%$ carbohydrate, and 17 to $24 \%$ oil, comprising $85 \%$ polyunsaturated fatty acids with two essential fatty acids. Soybean $(2 n=40)$ belongs to the Leguminosae family and is believed to have originated in northeastern China and distributed in the USA, Brazil, Argentina, China, India, etc. Today it ranks first in oilseed production (contribution $58 \%$ ) followed by rapeseed, groundnut, and sunflower. In India, it occupied an area of 10.97 mha with a production of $13.46 \mathrm{mt}$ and a productivity of $1120 \mathrm{~kg} \mathrm{ha}^{-1}$ (Anonymous, 
2018-19). In India, major soybean-producing states are Madhya Pradesh, Maharashtra, Rajasthan, Karnataka, Gujarat, Andhra Pradesh Uttar Pradesh and Chhattisgarh.

The continuous improvement of soybean depends on the information about genetic variability, genetic parameters, and their application, that assists the breeders in the reliable selection process. Important genetic parameters include heritability and genetic advance that enable the plant breeders to select the best breeding strategy. In this study was designed to estimate the genotypic coefficient of variance (GCV), phenotypic coefficient of variance (PCV), heritability (h2), expected genetic advance.

\section{Materials and Methods}

\section{Experimental materials}

For the purposed study consisted of 30 different soybean genotypes available with soybean breeder, Agricultural Research Station, Kasbe-Digraj, Sangli. The details of the 30 genotypes of soybean were given in Table 1.

\section{Experimental methods}

\section{Field experiment}

The field experiment consisting of 30 soybean genotypes was undertaken at Agricultural Research Station, Kasbe-Digraj, Sangli. To study recommended agronomic practices were followed to raise good crops. The detail of the experiment is as follows.
a) Season - Kharif, 2018
b) Design - RBD (Randomized Block Design)
c) Plot size - 5 X 2 meter
d) Date of sowing - 12 July 2018
e) Spacing - $45 \times 5 \mathrm{~cm}$

f) Number of genotypes - 30

g) Fertilizer Dose - 30: 60:30 Kg NPK/ha

\section{Details of observations Recorded}

Following observations on the five randomly selected plants from each experimental plot in each replication and averages were worked out viz., days to 50 percent flowering, days to maturity, plant height $(\mathrm{cm})$, number of primary branches per plant, number of pods per plant, number of seeds per pod, 100 seed weight $(\mathrm{g})$, seed yield per plant $(\mathrm{g})$, SPAD value, protein content $(\%)$, oil content $(\%)$

\section{Results and Discussion}

\section{Analysis of variance}

The analysis of variance for the eleven characters studied is presented in Table 2. The analysis revealed that all the genotypes exhibited highly significant differences for all the characters under study. These results confirmed the earlier findings of chandrawat et al., (2017), Joshi et al., (2017), Desissa (2017), and Koraddi and Baswaraja (2019).

\section{Variability and genetic parameters}

\section{Components of genetic variation}

Range of variability, estimates of components of variation, estimates of genotypic and phenotypic coefficient of variation, heritability percentage in a broad sense, genetic advance and genetic advance expressed as percentage of the mean are presented in Table 3 and Fig. 1.

\section{Estimates of components of variation}

It was observed that the estimates for phenotypic coefficients of variation (PCV) were higher than the genotypic coefficients of variation $(\mathrm{GCV})$ for all the characters studied. 
Similarly, the result observed by Neelima $e t$ al., (2018), the magnitude of genotypic coefficient variance was maximum for seed yield per plant (38.59) followed by the number of pods per plant (34.47). The phenotypic coefficient variance, however, ranged between 3.14 and 40.49 . It was of higher magnitude for seed yield per plant (40.49) followed by the number of pods per plant (35.37) While it was minimum for protein content percentage (3.14) followed by days to maturity (4.62).

Table.1 List of genotypes along with pedigree included in the studies

\begin{tabular}{|c|c|c|}
\hline Sr.no. & Name of genotype & Pedigree \\
\hline 1 & BAUS-100 & JS 20-30/JS 335 \\
\hline 2 & CAUMS-1 & Selection from NRC 2012-6-3-1-4-3 \\
\hline 3 & DS-3109 & Pusa 12/F4C7-32 \\
\hline 4 & DS-3110 & Pusa $12 / F 4 C 7-32$ \\
\hline 5 & DSb-33 & DSb 21/JS 95-60 \\
\hline 6 & GJS-3 & Germ plasm line KB - 85 \\
\hline 7 & Himso- 1688 & NRC 2007/B1-19 \\
\hline 8 & Himso-1689 & NRC 2008/G-1-12 \\
\hline 9 & JS-21-71 & JS 20-63/JS 95-60 \\
\hline 10 & JS-21-72 & SL 738/JS 95-60 \\
\hline 11 & KDS-1009 & AMS 99 33/EC 241780 \\
\hline 12 & KDS-1073 & JS 20-05/EC 241780 \\
\hline 13 & KS-113 & Selection from KS 103 \\
\hline 14 & MACS-1566 & RKS 24/NRC 55 \\
\hline 15 & MACS- 1620 & RKS 25/NRC 55 \\
\hline 16 & NRC-138 & JS 97-52/NRC 107 \\
\hline 17 & NRC-139 & JS 97-52/NRC 101 \\
\hline 18 & NRC-146 & Selection from 6A-34 \\
\hline 19 & NRC-147 & Indigenous collection (IC 210) \\
\hline 20 & NRC-148 & NRC 7/AGS 191 \\
\hline 21 & NRCSL-2 & JS 335/SL 525 EDV of JS 335 \\
\hline 22 & PS-1634 & JS 9752/PS 1225 \\
\hline 23 & PS-1637 & JS 9752/PK 472 \\
\hline 24 & RSC-11-15 & JS 335/PS 1024 \\
\hline 25 & RSC-11-17 & JS 97-52/JS 93-05 \\
\hline 26 & RVS-2007-4 & RVS 2000-10/JS 95-60 \\
\hline 27 & RVS-2011-10 & JS -335/PK 1042 \\
\hline 28 & KS-103 & JS 335/EC 241780 \\
\hline 29 & KDS -726 & JS 9305/EC 241780 \\
\hline 30 & KDS - 753 & JS 9305/EC 241780 \\
\hline
\end{tabular}


Table.2 Analysis of variance for different eleven characters in soybean

\begin{tabular}{|c|c|c|c|c|}
\hline Sr. No. & Character & \multicolumn{3}{|c|}{ Mean sum of square } \\
\hline & & Replication & Treatment & Error \\
\hline $\mathbf{1}$ & Df & $\mathbf{2}$ & $\mathbf{2 9}$ & $\mathbf{5 8}$ \\
\hline $\mathbf{2}$ & Days to 50\% flowering & 1.60 & $25.71^{* *}$ & 0.78 \\
\hline $\mathbf{3}$ & Days to maturity & 0.31 & $60.55^{* *}$ & 1.85 \\
\hline $\mathbf{4}$ & Plant height (cm) & 0.07 & $236.76^{* *}$ & 5.69 \\
\hline $\mathbf{5}$ & Number of primary branches & 0.04 & $0.30^{* *}$ & 0.04 \\
\hline $\mathbf{6}$ & Number of pods per plant & 9.26 & $514.20^{* *}$ & 8.93 \\
\hline $\mathbf{7}$ & Number of seeds per pod & 0.03 & $0.69^{* *}$ & 0.02 \\
\hline $\mathbf{8}$ & Seed yield per plant (g) & 2.79 & $28.62^{* *}$ & 0.92 \\
\hline $\mathbf{9}$ & 100 seed weight (g) & 1.15 & $16.94^{* *}$ & 1.40 \\
\hline $\mathbf{1 0}$ & SPAD Value & 2.02 & $47.77^{* *}$ & 5.01 \\
\hline $\mathbf{1 1}$ & Protein content (\%) & 2.52 & $2.79^{* *}$ & 0.97 \\
\hline
\end{tabular}

* Significant at 5\% level, ** Significant at $1 \%$ level, Values in parenthesis indicates the degrees of freedom

Table.3 Estimates of variability parameters for eleven different characters of soybean genotypes

\begin{tabular}{|c|c|c|c|c|c|c|c|c|}
\hline $\begin{array}{c}\text { Sr. } \\
\text { No. }\end{array}$ & Character & Mean & Range & $\begin{array}{c}\text { GCV } \\
(\mathbf{\%})\end{array}$ & $\begin{array}{c}\text { PCV } \\
(\mathbf{\%})\end{array}$ & $\begin{array}{c}\mathbf{h}^{\mathbf{2} \%} \\
\mathbf{( B . S . )}\end{array}$ & GA & $\begin{array}{c}\text { GA as percent } \\
\text { of mean (\%) }\end{array}$ \\
\hline $\mathbf{1}$ & Days to 50\% flowering & 40.86 & $35.33-46.33$ & 7.05 & 7.37 & 91.38 & 5.67 & 13.89 \\
\hline $\mathbf{2}$ & Days to maturity & 99.97 & $88.00-105.33$ & 4.42 & 4.62 & 91.36 & 8.70 & 8.71 \\
\hline $\mathbf{3}$ & Plant height (cm) & 43.32 & $32.06-68.31$ & 20.25 & 20.99 & 93.11 & 17.44 & 40.26 \\
\hline $\mathbf{4}$ & $\begin{array}{c}\text { Number of primary } \\
\text { branches }\end{array}$ & 3.41 & $3.00-4.00$ & 8.60 & 10.80 & 63.42 & 0.48 & 14.10 \\
\hline $\mathbf{5}$ & $\begin{array}{c}\text { Number of pods per } \\
\text { plant }\end{array}$ & 37.64 & $18.06-65.40$ & 34.47 & 35.37 & 94.96 & 26.05 & 69.20 \\
\hline $\mathbf{6}$ & $\begin{array}{c}\text { Number of seeds per } \\
\text { pod }\end{array}$ & 2.60 & $2.00-3.00$ & 18.27 & 19.13 & 91.18 & 0.93 & 35.93 \\
\hline $\mathbf{7}$ & Seed yield per plant (g) & 7.87 & $3.71-14.80$ & 38.59 & 40.49 & 90.87 & 5.96 & 75.79 \\
\hline $\mathbf{8}$ & \begin{tabular}{c} 
100 seed weight (g) \\
\hline $\mathbf{9}$
\end{tabular} & 13.11 & $10.01-18.31$ & 17.34 & 19.55 & 78.69 & 4.15 & 31.70 \\
\hline $\mathbf{1 0}$ & SPAD Value & 40.66 & $32.20-48.83$ & 9.28 & 10.79 & 73.99 & 6.68 & 16.44 \\
\hline $\mathbf{1 1}$ & Protein content (\%) & 40.00 & $38.10-41.66$ & 1.94 & 3.14 & 38.24 & 0.99 & 2.47 \\
\hline
\end{tabular}


Fig.1 Variability parameters for eleven different characters of soybean genotypes

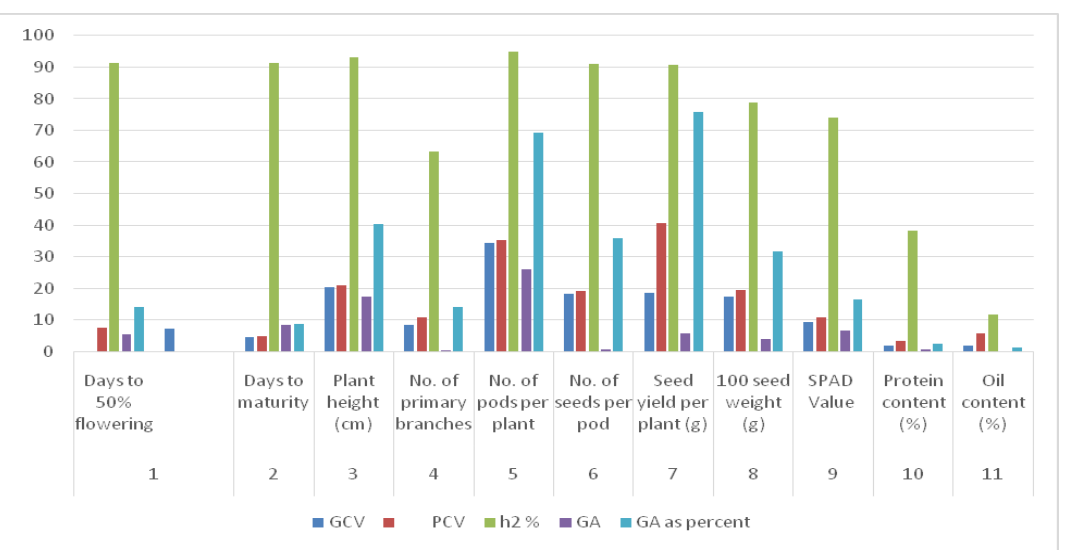

The highest difference between GCV and PCV values were observed for oil content (1.90-5.57), followed by 100 seed weight (17.34-19.55) and primary branches per plant (8.60-10.80). Days to maturity showed the lowest difference between GCV and PCV estimates (4.42-4.62). Koraddi and Baswaraja (2019) recorded the highest GCV and PCV for seed yield per plant. Joshi et al., (2017) reported the highest GCV and PCV for the number of branches and days to maturity. Chandel et al., (2013) estimated the highest GCV and PCV for plant height, number of seeds per pod, seed yield per plant. Ghodrati (2013) observed the highest GCV and PCV for primary branches per plant, pods per plant and plant height.

\section{Heritability (b.s.)}

The estimates of heritability (b.s.) presented in Table 3 and Fig. 1 ranged from 11.66 to $94.96 \%$. Maximum heritability observed for number of pods per plant (94.96), followed by plant height (93.11), days to 50 percent flowering (91.38) and minimum in case of oil content (11.66), followed by protein content (38.24) and number of primary branches per plant (63.42). Which confirmed with the finding of Jagdish et al., (2000) for seed yield per plant, pods per plant, and plant height. Chamundeshwari and Aher (2003) for plant height and number of pods per plant. Chandrawat et al., (2017) for pods per plant, plant height and seed yield per plant. Desissa (2017) for plant height.

\section{Genetic advance}

The range of genetic advance was between 0.25 to 26.05 with the highest estimates for the number of pods per plant (26.05), followed by plant height (17.44) and days to maturity (8.70). The lowest genetic advance was observed for oil content (0.25), followed by the number of primary branches per plant (0.48) and the number of seeds per pod (0.93). A similar result reported by Mahawar et al., (2013) recorded the low genetic advance for oil content. Mahbub and Shirazy (2016) recorded the highest genetic advance for the number of pods per plant, plant height, and number of branches per plant but in the present study, the number of primary branches per plant showed low genetic advance. Koraddi and Baswaraja (2019) recorded the highest genetic advance for plant height, number of pods per plant.

\section{Genetic advance as percent of mean}

The highest genetic advance as a percentage of mean was observed seed yield per plant (75.79) followed by the number of pods per 
plant (69.20) and plant height (40.26). Jagdish et al., (2000) and Neelima et al., (2018) recorded high genetic advance as a percentage of the mean for the number of pods per plant and plant height. Joshi et al., (2017) estimated high genetic advance as a percentage of the mean for plant height.

In the present investigation Phenotypic coefficient of variation (PCV) was found to be marginally higher than the genotypic coefficient of variation (GCV) for all the characters, indicating the dominance of the genotypic coefficient of variation for expression of these traits. Seed yield per plant exhibited the high GCV as well as PCV (38.59 and 40.49), number of pods per plant (34.47 to 35.37), plant height (20.25 and 20.99), number of seeds per pod (18.27 to 19.13) and 100 seed weight (17.34 and 19.55) respectively. Similarly, results observed by Neelima et al., (2018).

In conclusion the High estimates of genotypic coefficient of variation among the genotypes indicates variability for the characters viz., seed yield per plant, number of pods per plant, plant height, 100 seed weight. The magnitude of the phenotypic coefficient of variation was more than the genotypic coefficient of variation for all the characters. It can be concluded that the high Genotypic Coefficient of Variation (GCV) and Phenotypic Coefficient of Variation (PCV) coupled with high heritability indicates that there is a lesser influence of environment in the expression of characters which are amenable for selection. High heritability coupled with high genetic advance as percent of the mean indicated a preponderance of additive gene action in the inheritance of character like number of pods per plant and plant height and days to $50 \%$ flowering, days to maturity scope for selection in these characters.

References
Anonymous, 2018-19. All India Co-ordinated Research Project on soybean, Indore.

Burton, C. W. and Devane, E. H. 1952. Estimating heritability in tall Festuca (Restuca arundinacae) from replicated clonal material. Agron. J. 45: 14761481.

Chamundeshwari, N. and Aher, R. P. 2003. Genetic parameters of variation in growth characters and grain yield in soybean. Annals of Agriculture Biology Research, 8(1): 41-44.

Chandel, K. K., Patel, N. B. and Patel, J. B. 2013. Genetic Variability Analysis in Soybean [Glycine max (L.) Merril]. AGRES - An International e-Journal, 2(3): 318-325.

Chandrawat, K. S., Baig, K. S., Hashmi, S., Sarang, D. H., Kumar, A. and Dumai K. 2017. Study on Genetic Variability, Heritability and Genetic Advance in Soybean. Int. J. Pure App. Biosci., 5(1): 57-63.

Desissa, D. H. 2017. Genetic variability, Heritability and Genetic advances of soybean varieties. Asian J. of Plant Sciences and Research, 7(5): 20-26.

Ghodrati, G. H. 2013. Study of genetic variation and broad sense heritability for some qualitative and quantitative traits in soybean [Glycine max (L.) Merril] genotypes. Current Opinion in Agriculture, 2(1): 31-35.

Jagdish, Parmar, R.P. and Yadav, H.S. 2000. Assessment of genetic variability and selection parameters in early generation of soybean. Advances in Plant Sciences, 13(1): 227-232.

Johnson, H.W., Robinson, H. F. and Comstock, R. E. (1955). Estimates of genetic and environmental variability in soybean. Agron. J.,47: 314-318.

Joshi D., Pushpendra, Singh, K., and Adhikari, S. 2017. Study of genetic parameters in soybean germplasm 
based on yield and yield contributing traits. Indian J. Current Microbiological Applied Sciences, 7(1): 2319-7709.

Koraddi, S. and Baswaraja G. T. 2019. Genetic Variablity studies on yield and yield component traits of Soybean. Int.Curr. Microbiology and Applied Sci., 8(2): 1269-1274.

Mahbub, M. and Shirazy, B. J. 2016. Evaluation of Genetic Diversity in Different Genotypes of Soybean (Glycine max (L.) Merril). American J. of Plant Biology, 1(1): 24-29. Neelima G., Mhetre, S. P. and Narkhede, G. W. 2018. Genetic variability, Heritability and Genetic advances in soybean. International J. Pure and Applied Science, 6(2): 1011-1017.

Panse, V. G. and Sukhatme, P. V. 1957. Statistical Methods for Agricultural Workers. ICAR, New Delhi, 97-151.

Shivasubramanian, S. and Menon, M. 1973. Heterosis and inbreeding depression in rice. Madras Agricultural J., 60: 1139.

\section{How to cite this article:}

Pawar, M. G., S. B. Chaudhary, V. S. Pawar and Chavan, S. B. 2020. Study of Genetic Variability in Different Soybean Genotypes Based on Yield and Yield Contributing Traits. Int.J.Curr.Microbiol.App.Sci. 9(09): 426-433. doi: https://doi.org/10.20546/ijcmas.2020.909.054 